\title{
Agrarian sector of Ukraine in the global world
}

\author{
Y. Lupenko \\ National Scientific Centre „Institute of Agricultural Economics”, Kyiv, Ukraine \\ pd@iae.kiev.ua
}

SUMMARY

\begin{abstract}
Characterization of Ukraine as a "bread basket" for the world have been done. In our study using database of State statistical service of Ukraine and FAO we showed changes of harvest areas and volume of production of cereals and protein-oil crops during this century.

As a result we showed that Ukraine has increased its share in the world gross harvest of cereals up to 2.17\% and protein-oil crops up to $3.4 \%$. Each economically active agrarian produced 22.6 tons of cereals and 3.5 tons of protein-oil crops, increasing this index in comparing to 2000 in 11 and 12 times accordingly.

Ukraine has a great potential for increasing crop production because of use genetic potential of varieties only for 60-70\%. Here are shown changes in cattle, poultry breeding and dynamic of livestock production. We also included export of cereals and livestock production.
\end{abstract}

Keywords: cereals, protein-oil crops, harvest area, production, export

\section{INTRODUCTION}

Modern trends in forming the global community combined with minded people 'attempts to guide those trends in order to preserve humanity on our planet are implementing only in case of providing the world community with necessary amount of food, while creating for every person decent consumption conditions of high quality agricultural products and forming this how physically and mentally health person.

While this important role to meet needs of rapidly growing world population will be played by each country, which can produce not only to satisfy internal needs but also through mechanisms of global market provide its excess to the countries which are not able to provide themselves with food.

Substantive of global food problem is shown by Власов (2001), Саблук (2008), Білорус (2009), Супіханов (2009).

\section{MATERIALS AND METHOD}

Ukraine is one of such countries that is a «bread basket». Its role has increased significantly on global level as results of analysis of trends in the agricultural sector of Ukraine in the last decade. We used of Statistical database of State statistical service of Ukraine and FAO (Net 1.) to show a role of Ukraine as a significant producer and exporter of agricultural products.

\section{RESULTS}

According to statistical datas, harvest areas of major cereals and protein-oil crops has increased by surpassing rates (table 1). At the meanwhile in Ukraine, as well as in the world, the harvest areas of such plants as millet, oats and rye are reducing.

At the same time when global demand for the products of protein-oil crops (rapeseed, soybeans and sunflowers seed total) is increasing the country responded by rapid growth its areas - more than in 2.1 times against $34 \%$ over the world. While Ukraine's share was $8,6 \%$ of these $34 \%$ of global growth.

Such general trends in the area and productivity increase resulted in significant changes in the gross production of grain, oil and protein crops (table 2).

Table 1.

Trends of harvest area of cereals, protein-oil crops (thousands of hectares)

\begin{tabular}{|c|c|c|c|c|c|c|c|c|c|c|}
\hline \multirow[b]{2}{*}{ Culture } & \multicolumn{6}{|c|}{ Ukraine } & \multicolumn{4}{|c|}{ World } \\
\hline & 2000 & $\begin{array}{l}\% \text { to the } \\
\text { world }\end{array}$ & 2005 & 2011 & $\begin{array}{c}\% \text { to the } \\
\text { world }\end{array}$ & $\begin{array}{c}2011 \text { to } \\
2000(\%)\end{array}$ & 2000 & 2005 & 2011 & $\begin{array}{c}2011 \text { to } \\
2000(\%)\end{array}$ \\
\hline Maize & 1278.8 & 0.93 & 1659.5 & 3543.7 & 2.08 & 277.1 & 137004.8 & 147533.5 & 170398.1 & 124.4 \\
\hline Barley & 3689.1 & 6.77 & 4350.4 & 3684.2 & 7.58 & 99.9 & 54516.0 & 55361.8 & 48603.6 & 89.2 \\
\hline Millet & 366.5 & 0.99 & 120.4 & 156.4 & 0.49 & 42.7 & 37100.6 & 35484.0 & 31929.4 & 86.1 \\
\hline Rice & 25.2 & 0.02 & 21.4 & 29.6 & 0.02 & 117.5 & 154059.9 & 154987.4 & 164125.0 & 106.5 \\
\hline Rye & 638.1 & 6.50 & 608.9 & 279.1 & 5.46 & 43.7 & 9817.4 & 6802.8 & 5113.1 & 52.1 \\
\hline Sorghum & 14.4 & 0.03 & 20.1 & 66.7 & 0.19 & 463.2 & 41186.8 & 46530.7 & 35482.8 & 86.2 \\
\hline Cereals, total & 12203.6 & 1.81 & 14204.6 & 14985.2 & 2.15 & 122.8 & 672991.0 & 690507.0 & 697687.7 & 103.7 \\
\hline Rapeseed & 156.7 & 0.61 & 195.2 & 832.7 & 2.47 & 531.4 & 25843.9 & 27680.7 & 33645.3 & 130.2 \\
\hline
\end{tabular}


Trends of production of cereals and protein-oil crops (million tonnes)

\begin{tabular}{|c|c|c|c|c|c|c|c|c|c|c|}
\hline \multirow[b]{2}{*}{ Culture } & \multicolumn{6}{|c|}{ Ukraine } & \multicolumn{4}{|c|}{ World } \\
\hline & 2000 & $\begin{array}{c}\% \text { to the } \\
\text { world }\end{array}$ & 2005 & 2011 & $\begin{array}{c}\% \text { to the } \\
\text { world }\end{array}$ & $\begin{array}{c}2011 \text { to } \\
2000(\%)\end{array}$ & 2000 & 2005 & 2011 & $\begin{array}{c}2011 \text { to } \\
2000(\%)\end{array}$ \\
\hline Wheat & 10.2 & 1.74 & 18.7 & 22.3 & 3.17 & 218.9 & 585.7 & 626.9 & 704.1 & 120.2 \\
\hline Maize & 3.8 & 0.64 & 7.2 & 22.8 & 2.58 & 593.5 & 592.5 & 713.6 & 883.5 & 149.1 \\
\hline Barley & 6.8 & 5.11 & 9.0 & 9.1 & 6.78 & 132.4 & 133.1 & 138.7 & 134.3 & 100.9 \\
\hline Millet & 0.4 & 1.44 & 0.1 & 0.3 & 1.08 & 65.4 & 27.7 & 30.9 & 27.7 & 100.1 \\
\hline Oat & 0.9 & 3.45 & 0.8 & 0.5 & 2.22 & 57.4 & 26.1 & 23.7 & 22.5 & 86.2 \\
\hline Rice & 0.09 & 0.02 & 0.09 & 0.2 & 0.03 & 189.4 & 599.3 & 634.4 & 722.8 & 120.6 \\
\hline Rye & 0.9 & 4.48 & 1.0 & 0.6 & 4.65 & 59.8 & 20.1 & 15.1 & 12.9 & 64.4 \\
\hline Sorghum & 0.02 & 0.04 & 0.05 & 0.2 & 0.37 & 1066.1 & 55.8 & 60.1 & 54.2 & 97.0 \\
\hline Cereals, total & 23.8 & 1.16 & 37.2 & 56.2 & 2.17 & 236.3 & 2060.6 & 2268.7 & 2587.1 & 125.6 \\
\hline Rapeseed & 0.1 & 0.25 & 0.3 & 1.4 & 2.24 & 1090.7 & 39.5 & 50.0 & 62.4 & 158.0 \\
\hline Soybeans & 0.06 & 0.04 & 0.6 & 2.3 & 0.88 & 3516.1 & 161.3 & 214.5 & 260.9 & 161.8 \\
\hline Sunflower seed & 3.4 & 12.83 & 4.7 & 8.7 & 21.64 & 250.8 & 26.5 & 30.8 & 40.2 & 151.4 \\
\hline Protein-oil crops, total & 3.7 & 1.63 & 5.6 & 12.4 & 3.41 & 338.6 & 227.4 & 295.3 & 363.6 & 159.9 \\
\hline
\end{tabular}

If in 2000 Ukraine's share in the world gross harvest of cereals was $1.16 \%$, protein-oil crops $1.63 \%$, but in 2011 its share grew to 2.17 and $3.41 \%$ accordingly. That is why, country that has only $0.19 \%$ economically active rural population to world's produces 22.6 tonnes of cereals and 3.5 tonnes of protein-oil crops on one economically active agrarian against accordingly about 2 and 0.3 tones in 2000 year, or in 11 and 12 times more.

Greatest increase of production in Ukraine is being by such crops as maize (in 6 times against 2000), sorghum and rapeseed (almost in 11 times), soybean (in 35 times). While this Ukraine uses genetic potential of varieties that are applied only for $60-70 \%$. Thus on varietal plots the yield of different varieties of cereals is on 23-32 cwt/ha more than the average for agricultural producers. Average yield of winter and spring wheat is $59.5-81.2 \mathrm{cwt} / \mathrm{ha}$, barley $-33.8-42.6$, maize $-65.4-107.2 \mathrm{cwt} / \mathrm{ha}$ against average yield in 2011 in Ukraine 33.5; 24.7; 64.4 cwt ha ${ }^{-1}$.

Implementation of technologies, which could provide a more complete realization of genetic potential of varieties will allow Ukraine to gain additional 15-17 million tonnes of cereals. But still nowadays Ukraine has all opportunities for annual export of 20-25 million tonnes of cereals and participation in forming UN strategic grain reserves on its area scoped by 10 million tonnes addressed to cover needs of other countries in case of various climatic or political turmoil.

Dynamic of animal production is quite different against the background of real progress in the production of crops. In particular with forced transition from a planned to a free market economy stock of animals reduced significantly (table 3). Therefore livestock production volumes reduced as well. Simultaneously the pig and sheep breeding where the reduction was not so considerable and also poultry breeding, which volumes increased almost in 1.5 times, the production volumes increased (table 4).

Poultry meat production increased in 5.1 times along with reduction of beef production almost in 2 times. This allowed increasing of total meat production by international rates -27 and $28.9 \%$ accordingly.

In contrast to global trends Ukraine has reduced the milk and butter production with a significant excess of global growth indicators of cheese and eggs.

That is why, while reducing the share of Ukraine to the World by beef and pork production by increasing the production of poultry meat the country has maintained its position in general by meat on $0.71 \%$ level in 2000 and $0.72 \%$ in 2011 . All along with increasing the proportion of cheese production from $0.5 \%$ to $1.01 \%$ and eggs from 0.92 to $1.55 \%$.

Dynamics of stock and poultry (million of heads)

\begin{tabular}{|c|c|c|c|c|c|c|c|c|c|c|}
\hline \multirow[b]{2}{*}{ Index } & \multicolumn{6}{|c|}{ Ukraine } & \multicolumn{4}{|c|}{ World } \\
\hline & 2000 & $\begin{array}{l}\% \text { to the } \\
\text { world }\end{array}$ & 2005 & 2011 & $\begin{array}{l}\% \text { to the } \\
\text { world }\end{array}$ & $\begin{array}{c}2011 \text { to } \\
2000(\%)\end{array}$ & 2000 & 2005 & 2011 & $\begin{array}{l}2011 \text { to } \\
2000(\%)\end{array}$ \\
\hline Cattle & 10.63 & 0.81 & 6.90 & 4.49 & 0.32 & 42.3 & 1313.3 & 1367.9 & 1399.9 & 106.6 \\
\hline including cows & 5.27 & 2.39 & 3.85 & 2.59 & 1.02 & 49.1 & 220.40 & 240.27 & 253.47 & 115.0 \\
\hline Pigs & 10.07 & 1.12 & 6.47 & 7.96 & 0.83 & 79.0 & 898.91 & 905.43 & 963.04 & 107.1 \\
\hline Sheep and goats & 1.88 & 0.10 & 1.75 & 1.73 & 0.09 & 91.9 & 1811.16 & 1939.14 & 1919.24 & 106.0 \\
\hline Broilers & 118.00 & 0.82 & 131.98 & 183.60 & 0.92 & 155.6 & 14359.03 & 17135.15 & 19939.33 & 138.9 \\
\hline Ducks & 20.00 & 2.06 & 8.39 & 10.78 & 0.79 & 53.9 & 969.14 & 1118.12 & 1363.16 & 140.7 \\
\hline Turkey cock & 1.00 & 0.22 & 2.37 & 1.88 & 0.41 & 188.0 & 457.25 & 446.07 & 462.96 & 101.2 \\
\hline Whole poultry & 139.00 & 0.87 & 152.08 & 202.53 & 0.91 & 145.7 & 16054.06 & 19051.17 & 22168.16 & 138.1 \\
\hline
\end{tabular}


Dynamics of livestock production (thousand tonnes)

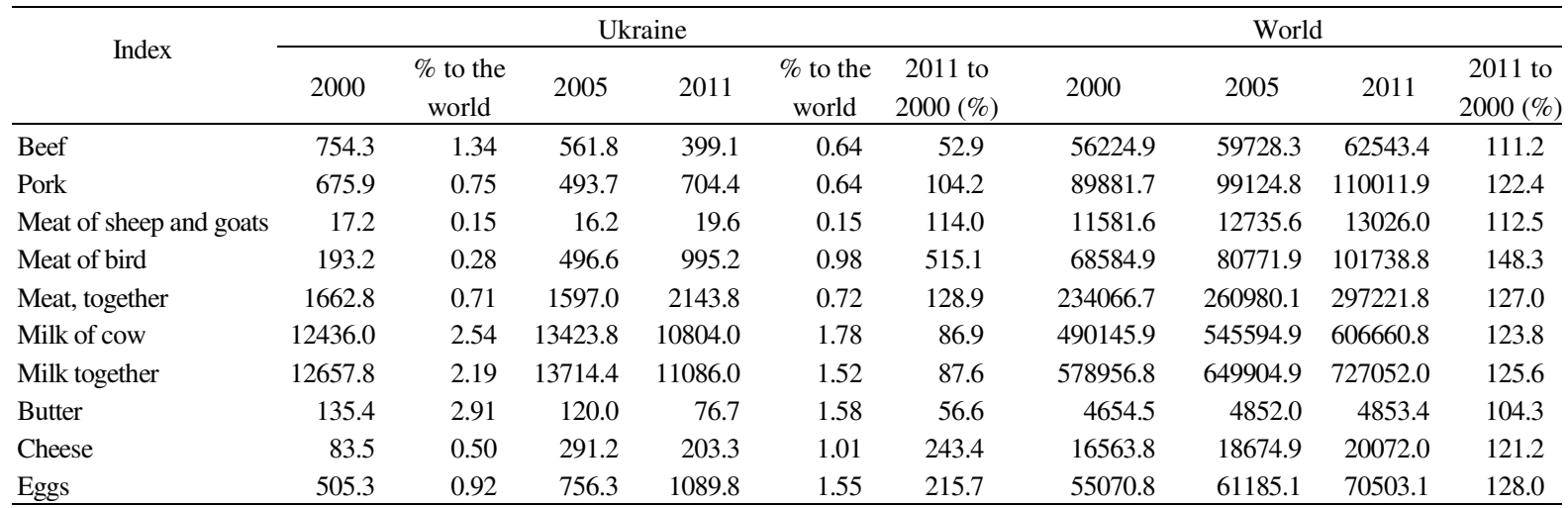

Ukraine relatively recent entered the world market as independent state has significantly strengthened it presence in foreign markets. Thus if in 2000 Ukraine exported 200,1 thousand tonnes of wheat, 163.2 thousand tonnes of maize, 864.7 thousand tonnes of barley and nearly 1.3 million tonnes of cereals in total, so that in 2010 - accordingly 3.3 million tonnes, almost 4.6 and 12.1 million tonnes, in other words in 21.4, 17.7, 5.3 and 9.4 times more.
Increasing exports of crop production allowed to raise the proportion of the country in the aggregate by cereals from $0.47 \%$ in 2000 to $3.55 \%$ in 2010 on the world level. Where export of wheat increased from 0.17 to $2.96 \%$, export of maize - from 0.2 to $2.68 \%$, export of barley - from 3.62 to $17.35 \%$ (table 5).

Due to such trends in 2011 Ukraine became one of three largest world exporters of grains and the largest exporter of barley.

Table 5 .

Trends in export of cereals, protein and oil crops (thousand tonnes)

\begin{tabular}{lrrrrrrrrrr}
\hline & \multicolumn{1}{c}{ Culture } & \multicolumn{3}{c}{ Ukraine } & \multicolumn{3}{c}{ World } \\
\cline { 2 - 10 } & 2000 & $\begin{array}{c}\text { \% to the } \\
\text { world }\end{array}$ & 2005 & 2011 & $\begin{array}{r}\text { \% to the } \\
\text { world }\end{array}$ & $\begin{array}{r}2011 \text { to } \\
2000(\%)\end{array}$ & 2000 & 2005 & 2011 & $\begin{array}{c}2011 \text { to } \\
2000(\%)\end{array}$ \\
\cline { 2 - 11 } Wheat & 201.1 & 0.17 & 6009.5 & 4302.8 & 2.96 & 2139.6 & 117190.1 & 120468.0 & 145158.6 & 123.9 \\
Maize & 163.2 & 0.20 & 2795.6 & 2888.3 & 2.68 & 1769.8 & 82354.1 & 90418.9 & 107864.9 & 131.0 \\
Barley & 864.7 & 3.62 & 3501.8 & 4593.3 & 17.35 & 531.2 & 23883.8 & 25802.2 & 26469.1 & 110.8 \\
Rice & 0.1 & 0.00 & 0.7 & 3.1 & 0.01 & 3100.0 & 23547.3 & 29503.8 & 32768.3 & 139.2 \\
Rye & 18.4 & 0.80 & 80.5 & 93.3 & 6.74 & 507.1 & 2296.4 & 2015.9 & 1385.1 & 60.3 \\
Cereals, total & 1285.7 & 0.47 & 12518.9 & 12075.5 & 3.55 & 939.2 & 273087.9 & 291384.7 & 339846.1 & 124.4 \\
Rapeseed & 68.6 & 0.71 & 183.4 & 1182.9 & 7.03 & 1724.3 & 9693.6 & 8665.0 & 16831.0 & 173.6 \\
Soybeans & 7.7 & 0.02 & 174.6 & 195.7 & 0.21 & 2541.6 & 47377.8 & 65382.0 & 93383.9 & 197.1 \\
Sunflower & 833.7 & 21.67 & 35.6 & 308.0 & 8.23 & 36.9 & 3846.9 & 3114.4 & 3743.9 & 97.3 \\
Protein-oil crops, total & 910.0 & 1.49 & 393.6 & 1686.6 & 1.48 & 185.3 & 60918.3 & 77161.4 & 113958.8 & 187.1 \\
Flour & 1.4 & 0.02 & 18.8 & 72.6 & 0.63 & 5185.7 & 9052.7 & 10000.3 & 11440.4 & 126.4 \\
\hline
\end{tabular}

Ukraine became the largest exporter of sunflower oil as well, took the world's second place by the volume of its production and third place by sunflower seed production. If in 2000 share of Ukrainian goods on the World market was $15.3 \%$ so that in 2010 it grew up to $39.7 \%$ or more in 2 times. While this Ukrainian export grew in 3.6 times against $48.2 \%$ of the world. Increasing of sunflower oil of the world export from 2000 to 2010 was 1.8 mil tons, 1.5 mil of which were in Ukraine.

Concerning the export of livestock production Ukraine has drastically worsened its position on the world market by most products (table 6). Simultaneously share of Ukrainian exports by poultry meat, eggs, cheese and milk has increased slightly.
In other words, Ukraine took its rightful place among the group of leaders by the export of cereals, protein-oil crops while reinforcing its position on a number of products processing industry.

As follows, agricultural sector of Ukraine after certain losses is significantly increasing volume of agricultural production, especially crop production and expands its presence in the world market. Significant export proportion of certain types of crops and sunflower oil suggests strengthening the competitive position of Ukraine in the global world, increasing its capacity in solving the food problem. It should be born in mind that Ukraine's potential to increase production and export of animal products (except poultry production) is still untapped and there is good reason to increase the share of Ukraine in external markets of those products. 
Dynamics of export of livestock products (tonnes)

\begin{tabular}{|c|c|c|c|c|c|c|c|c|c|c|}
\hline \multirow[b]{2}{*}{ Index } & \multicolumn{6}{|c|}{ Ukraine } & \multicolumn{4}{|c|}{ World } \\
\hline & 2000 & $\begin{array}{c}\% \text { to the } \\
\text { world }\end{array}$ & 2005 & 2011 & $\begin{array}{c}\% \text { to the } \\
\text { world }\end{array}$ & $\begin{array}{c}2011 \text { to } \\
2000(\%)\end{array}$ & 2000 & 2005 & 2011 & $\begin{array}{c}2011 \text { to } \\
2000(\%)\end{array}$ \\
\hline Pig meat & 13173 & 0.19 & 10948 & 341 & 0.003 & 2.6 & 6951983 & 10074251 & 12754183 & 183.5 \\
\hline Meat of sheep and goats & 390 & 0.04 & 36 & 1 & 0.0001 & 0.26 & 959178 & 1010305 & 1015600 & 105.9 \\
\hline Poultry meat & 960 & 0.01 & 13348 & 27170 & 0.18 & 2830.2 & 8780674 & 10960953 & 15383533 & 175.2 \\
\hline Cow milk & 350 & 0.01 & 1783 & 13725 & 0.17 & 3921.4 & 4852893 & 5813522 & 8113498 & 167.2 \\
\hline Butter & 31304 & 2.4 & 24369 & 945 & 0.06 & 3.0 & 1302214 & 1499861 & 1604553 & 123.2 \\
\hline Cheeses & 12468 & 0.38 & 116229 & 65383 & 1.2 & 524.4 & 3305791 & 4287302 & 5442982 & 164.6 \\
\hline Milk products & 672381 & 0.92 & 1505539 & 588037 & 0.56 & 87.5 & 72860862 & 86392047 & 104142396 & 142.9 \\
\hline Eggs & 375 & 0.04 & 1031 & 18558 & 0.89 & 4948.8 & 955302 & 1162217 & 2085451 & 218.3 \\
\hline
\end{tabular}

\section{REFERENCES}

Білорус, О. Г.-Зубець, М. В.-Саблук, П.Т.-Власов, В.І. (2009): Глобальна продовольча безпека. ННЦ «IAЕ». 486.

Саблук, П. Т.-Власов, В. І.-Біленький, О. Ю. (2010): Регіональна інтеграція. ННЦ «ІАЕ», Київ. 366.

Супіханов, Б. К. (2009): Розвиток ринків аграрної продукції. 2 вид., допов. і перероб. ННЦ «ІАЕ», Київ. 530.
Державна служба статистики України

Net 1: www.fao.org.

Власов, В. І. (2001): Глобальна продовольча проблема. Інститут світової економіки і міжнародних відносин НАН України, Інститут аграрної економіки УААН, Київ. 506. 